\title{
Compatibility of portland cement and polycarboxylate-based superplasticizers in high-strength concrete for precast constructions
}

\author{
Совместимость портландцемента \\ и суперпластификаторов на поликарбоксилатной основе \\ для получения высокопрочного бетона сборных конструкций
}

\author{
O.M. Smirnova, \\ Petersburg State Transport University, \\ St. Petersburg, Russia
}

\author{
Канд. техн. наук, доцент О.М. Смирнова, \\ Петербургский государственный \\ университет путей сообщения \\ Императора Александра I, \\ г. Санкт-Петербург, Россия
}

Key words: building materials; construction; precast concrete; heat-steaming treatment; polycarboxylate-based superplasticizer; stiff fresh concrete

\author{
Ключевые слова: строительство; \\ строительные материалы; сборный бетон; \\ тепловлажностная обработка; \\ суперпластификатор на поликарбоксилатной \\ основе; жесткая бетонная смесь
}

Abstract. Application of polycarboxylate-based superplasticizers can contribute to the increase of concrete early strength. It makes possible to obtain the concrete of the required strength after heatsteaming treatment with decreasing the isothermal temperature and the Portland cement quantity compared to the concrete without admixtures. Reducing of water-cement ratio and lack of accelerated high-temperature of heat-steaming treatment raises the durability of precast concrete. The use of low heat-steaming treatment must not lead to an increase of the duration of treatment and reduction of productivity of plant with double turnover of moulds per day. It is necessary to take into account the compatibility of Portland cement and polycarboxylate-based superplasticizers to obtain the high concrete strength after heat-steaming treatment. The problem of the compatibility of Portland cement and polycarboxylate-based superplasticizers in precast concrete production contains the following items: the influence of chemical and mineralogical compositions of Portland cement on the water-reducing effect of polycarboxylate-based superplasticizers, on the retention of workability of fresh concrete as well as on the growth of early concrete strength. Most of the published papers contain the results received when investigating the cement paste. However, the effect of polycarboxylate-based superplasticizers in stiff fresh concrete has not yet been fully investigated. The optimal dosages of polycarboxylate-based superplasticizers, requirements to the granulometric and chemical-mineralogical compositions of Portland cements with the purpose of reducing the cement consumption and providing the required concrete strength after the heat-steaming treatment at $40^{\circ} \mathrm{C}$ have been defined.

Аннотация. Применение поликарбоксилатных суперпластификаторов позволяет получать высокопрочный бетон и может способствовать повышению ранней прочности бетона. Это дает возможность получать бетон с требуемой прочностью после тепловлажностной обработки (ТВО) при снижении температуры изотермической выдержки и расхода портландцемента по сравнению с бетоном без добавок. При этом необходимо учитывать совместимость портландцемента и поликарбоксилатного суперпластификатора. В области производства сборного бетона и железобетона под вопросом совместимости портландцементов с суперпластификаторами следует понимать влияние химико-минералогического состава портландцемента на водоредуцирующее действие добавок, исключение быстрой потери подвижности бетонной смеси, почасовую кинетику набора ранней прочности бетона с суперпластификатором. Большая часть работ отражает результаты, полученные на цементном тесте. Однако эти вопросы не исследованы для жестких бетонных смесей. Установлены оптимальные расходы суперпластификаторов, требования к гранулометрическому и химико-минералогическому составу портландцементов с целью снижения расхода цемента и обеспечения требуемой прочности бетонов после ТВО продолжительностью 12 
часов при температуре изотермической выдержки $40{ }^{\circ} \mathrm{C}$. Получены зависимости прочности бетона после ТВО от расхода портландцемента и поликарбоксилатных суперпластификаторов.

\section{Introduction}

Application of polycarboxylate-based superplasticizers can contribute to the increase of concrete early strength. It makes possible to obtain the concrete of the required strength after heat-steaming treatment with decreasing the isothermal temperature and the Portland cement quantity compared to the concrete without admixtures. Steaming at high temperatures reduces a number of technical characteristics of concrete such as strength at age of 28 days and frost resistance [1]. Reducing of watercement ratio and the lack of accelerated high-temperature of heat-steaming treatment raises durability of precast concrete due to the improvement of the concrete structure [2-6]. The use of low heat-steaming treatment must not lead to an increase of the duration of treatment and reduction of productivity of plant.

It is necessary to take into account the incompatibility of Portland cement and polycarboxylatebased superplasticizers to obtain the high concrete strength after heat-steaming treatment. Such concrete should provide the required transfer strength (strength at the moment of release tension bars) in a relatively short time 10-12 hours. For example, with double turnover moulds per day at the plant the concrete strength of class B40 should be not less than $35 \mathrm{MPa}$ at the age of $10-12$ hours and $44 \mathrm{MPa}-$ for concrete strength of class B50.

Considering the problem of the incompatibility of Portland cement and polycarboxylate-based superplasticizers in precast concrete production it is necessary to take into account the influence of chemical and mineralogical compositions of Portland cement on the water-reducing effect of polycarboxylate-based superplasticizers, on the retention of workability of fresh concrete as well as on the growth of early concrete strength.

Considerable decrease of water quantity in fresh concrete mixes of equal workability by means of introducting small dosages of polycarboxylate-based superplasticizer accelerates the Portland cement hydration. On the other hand, the increased dosages of polycarboxylate-based superplasticizer slow down the Portland cement hydration in spite of their high water-reducing effect.

The authors $[7,8]$ highlight the role of a soluble alkali and $\mathrm{C}_{3} \mathrm{~A}$ in the retention of workability of fresh cement paste.

The papers published on incompatibility theme can be classified into the following subjects depending on the factor studied: chemical and mineralogical compositions of Portland cement (quantity of $\mathrm{C}_{3} \mathrm{~A}, \mathrm{Na}_{2} \mathrm{O}_{\text {equiv }}, \mathrm{SO}_{3}$ ) and its fineness [9-10]; fineness and quantity of mineral fillers [11-15]; quantity of admixture [12, 16]; chemical base of admixture, structure of its molecule [17], speed of polycarboxylatebased superplasticizer adsorption on the cement particles being hydrated [18-23].

The mineral additions in Portland cement impact rheology of cement paste and affect the interaction between superplasticizers and cements. The results of paper [11] show that cementsuperplasticizers compatibility is altered by the physical (specific surface) and chemical (surface charge) characteristics of the mineral additions (limestone, fly ash and silica fume). In paper [14] it has investigated the incompatibility of Blended cement and polycarboxylate-based superplasticizers in range from 0.7 to $1.2 \%$. The delay of admixtures on cement hydration intensifies with rising PCE dosage. This admixture-mediated retarding effect was also observed to vary depending on the nature of the addition, and was most intense in slag-blended cement.

Most of the published papers contain the results received when investigating the cement paste. However, the effect of polycarboxylate-based superplasticizer in stiff fresh concrete has not yet been fully investigated. It is necessary to specify to what changes in admixture dosage or water quantity as well as in concrete strength development the changing Portland cement properties can lead to. The results of the research can be used in the production of precast prestressed reinforced concrete with polycarboxylatebased superplasticizers on the existing technological lines of plants with double turnover of moulds per 24 hours.

\section{Materials and methods of research}

For research it was selected the domestic Portland cements PC500-D0-N of six manufacturers corresponding to Russian Standard GOST 30515-97 "Cements. General technical conditions" and CEM I 42.5N from two factories corresponding to Russian Standard GOST 31108-2003 "Cements. Technical conditions". Chemical and mineralogical compositions of Portland cements are presented in

Смирнова О.М. Совместимость портландцемента и суперпластификаторов на поликарбоксилатной основе для получения высокопрочного бетона сборных конструкций // Инженерно-строительный журнал. 2016. № 6(66). C. 12-22. 
Tables 1 and 2. Most of Portland cements had the content of $\mathrm{C}_{3} \mathrm{~S}$ within $60 \%$ and the content of $\mathrm{C}_{3} \mathrm{~A}-$ 6-9\%. Such Portland cements are the most effective in the precast concrete production under conditions of heat-steaming treatment at temperature $80^{\circ} \mathrm{C}$. As polycarboxylate-based superplasticizers it was selected those, which due to their certain molecule structure are able to increase the concrete early strength. These are: Glenium ACE 430, Sika Viscocrete 20 Gold. The sand and crushed stone aggregates were according to Russian Standards GOST 8736-93 and GOST 8267-93. The control sample was prepared from the concrete mix (Portland cement $470 \mathrm{~kg} / \mathrm{m}^{3}$ ) used in the production of precast prestressed reinforced concrete with the double turnover of moulds every 24 hours and heatsteaming treatment at the isothermal temperature of $80^{\circ} \mathrm{C}$. The workability of fresh concrete was $18-20$ seconds.

Table 1. Chemical compositions of Portland cements

\begin{tabular}{|c|c|c|c|c|c|c|c|c|c|c|c|c|}
\hline $\begin{array}{c}\mathrm{No} \text { of } \\
\text { sample }\end{array}$ & $\mathrm{Cement}$ & $\mathrm{CaO}$ & $\mathrm{SiO}_{2}$ & $\mathrm{Al}_{2} \mathrm{O}_{3}$ & $\mathrm{Fe}_{2} \mathrm{O}_{3}$ & $\mathbf{M g O}$ & $\mathbf{S O}_{3}$ & $\mathrm{~K}_{2} \mathrm{O}$ & $\mathrm{Na}_{2} \mathrm{O}$ & $\begin{array}{c}\mathrm{Na}_{2} \mathrm{O} \\
\text { eqv }\end{array}$ & $\begin{array}{c}\mathrm{CaO} \\
\text { cв }\end{array}$ & L.O.I. \\
\hline 1 & $\begin{array}{c}\mathrm{CEM} \mathrm{I} \\
42.5 \mathrm{~N}\end{array}$ & 63.80 & 21.20 & 4.90 & 3.90 & 1.00 & 2.80 & 0.60 & 0.13 & 0.52 & 0.30 & 1.10 \\
\hline 2 & $\begin{array}{c}\text { PC500- } \\
\text { DO-N }\end{array}$ & 63.90 & 21.00 & 4.88 & 4.12 & 0.92 & 2.77 & 0.58 & 0.17 & 0.55 & 0.25 & 1.00 \\
\hline 3 & $\begin{array}{c}\mathrm{CEM} \mathrm{I} \\
42.5 \mathrm{~N}\end{array}$ & 66.20 & 21.60 & 5.77 & 4.12 & 1.09 & 2.50 & 0.57 & 0.30 & 0.68 & - & 1.06 \\
\hline 4 & $\begin{array}{c}\text { PC500- } \\
\text { D0-N }\end{array}$ & 65.97 & 21.41 & 5.67 & 5.12 & 0.80 & 2.57 & 0.68 & 0.31 & 0.76 & - & 0.86 \\
\hline 5 & $\begin{array}{c}\text { PC500- } \\
\text { D0-N }\end{array}$ & 63.79 & 21.26 & 3.67 & 3.54 & 1.75 & 2.76 & 0.59 & 0.76 & 1.15 & - & 1.17 \\
\hline 6 & $\begin{array}{c}\text { PC500- } \\
\text { D0-N }\end{array}$ & 65.74 & 21.50 & 4.96 & 5.32 & 1.32 & 2.60 & 0.57 & 0.32 & 0.69 & 0.07 & 0.33 \\
\hline 7 & $\begin{array}{c}\text { PC500- } \\
\text { D0-N }\end{array}$ & 63.56 & 20.56 & 5.21 & 4.13 & 1.41 & 2.82 & 0.65 & 0.36 & 0.79 & - & 0.94 \\
\hline 8 & $\begin{array}{c}\text { PC500- } \\
\text { D0-N }\end{array}$ & 61.90 & 19.70 & 4.92 & 3.30 & 3.90 & 3.12 & 0.67 & 0.71 & 1.15 & - & - \\
\hline
\end{tabular}

The following methods were used: analysis of the particle size distribution (the laser particle size distribution analyzer - MicroSizer 201), termokinetic analysis (Calvet-type calorimeter), scanning electron microscopy (Supra55VP-3249 Zeiss). The kinetics of the plastic strength growth of the cement paste was investigated using a cone plastometer following the methodology of academician P.A. Rebinder [24]. The tests were conducted at intervals of cone immersing, equal to 30 minutes. As the criterion were used the value of the plastic strength in MPa, which was determined from the expression:

$$
P_{m}=K \cdot \frac{F \cdot g}{100000 \cdot h^{2}}
$$

where $\mathrm{F}$ - the load in $\mathrm{g}$;

$\mathrm{h}$ - depth of cone immersion in $\mathrm{cm}, \mathrm{h}=1 \mathrm{~cm}$;

$\mathrm{K}$ - coefficient depending on the angle of the cone at the top, at $45^{\circ} \mathrm{K}=0.656$.

The results of defining the plastic strength are expressed graphically in the form of plastograms, on which one can distinguish specific periods: the initial period (induction period) and that of rapid growth plastic strength. 
Table 2. Mineralogical compositions of Portland cements

\begin{tabular}{|c|c|c|c|c|}
\hline $\begin{array}{c}\text { No of } \\
\text { sample }\end{array}$ & $\mathbf{C}_{3} \mathbf{S}$ & $\mathbf{C}_{2} \mathbf{S}$ & $\mathbf{C}_{3} \mathbf{A}$ & $\mathbf{C}_{4} \mathbf{A F}$ \\
\hline 1 & 63.0 & 14.7 & 6.5 & 13.0 \\
\hline 2 & 63.1 & 14.6 & 6.3 & 13.5 \\
\hline 3 & 64.4 & 14.3 & 9.9 & 11.0 \\
\hline 4 & 59.1 & 17.0 & 6.2 & 15.5 \\
\hline 5 & 66.4 & 14.6 & 4.2 & 10.7 \\
\hline 6 & 63.9 & 13.0 & 4.1 & 16.0 \\
\hline 7 & 65.0 & 9.4 & 6.4 & 12.4 \\
\hline 8 & 62.1 & 10.4 & 6.9 & 11.3 \\
\hline
\end{tabular}

\section{Results and discussion}

Comparison of particle size distribution of the selected Portland cements showed that there are fewer particles having the grains size less than 2, 3, 5 and $10 \mu \mathrm{m}$ in Portland cements No. 1, 2, 3, 4 than in the other Portland cements (Table 3).

Table 3. The particle size distribution of Portland cements

\begin{tabular}{|c|c|c|c|c|c|c|}
\hline \multirow{2}{*}{$\begin{array}{c}\text { No } \\
\text { of } \\
\text { sample }\end{array}$} & \multicolumn{6}{|c|}{ Содержание зерен размером менее, \% } \\
\cline { 2 - 7 } & $\mathbf{2}$ & $\mathbf{3}$ & $\mathbf{5}$ & $\mathbf{1 0}$ & $\mathbf{1 6}$ & $\mathbf{3 2}$ \\
$\mathbf{\text { мкм }}$ & $\mathbf{\text { мкм }}$ & $\mathbf{\text { мкм }}$ & $\begin{array}{c}\text { мкм } \\
\text { мкм }\end{array}$ \\
\hline 1 & 9.9 & 15.9 & 25.7 & 37.8 & 59.6 \\
\hline 2 & 6.3 & 8.6 & 14.1 & 23.7 & 48.8 & 68.9 \\
\hline 3 & 9.7 & 13.6 & 20.2 & 33.8 & 44.2 & 71.6 \\
\hline 4 & 9.0 & 12.5 & 19.8 & 36.7 & 47.1 & 72.6 \\
\hline 5 & 14.8 & 20.8 & 28.7 & 42.9 & 51.3 & 70.7 \\
\hline 6 & 11.6 & 16.6 & 23.7 & 38.6 & 49.2 & 75.2 \\
\hline 7 & 6.6 & 11.5 & 24.0 & 38.9 & 45.8 & 71.0 \\
\hline 8 & 13.9 & 19.7 & 27.4 & 42.2 & 51.8 & 73.8 \\
\hline
\end{tabular}

Setting time can be estimated on cement pastes through the Vicat needle method. A recent study $[25,26]$ suggested improving the Vicat test by using a static method that allows monitoring of the evolution of the setting starting immediately from the mixing time. Based on ultrasound techniques, a new testing device is suggested to analyze setting and hardening of concrete materials. In this paper the cone plastometer of academician P.A. Rebinder are proposed. This method allows also monitoring of the evolution of the setting starting immediately from the mixing time [27].

By comparing the kinetics of the plastic strength development it was found out that Portland cements, which have a shorter initial period (induction period) of hardening and more intensive plastic strength development in the second period of hardening, contained the increased number of grains of size less than $10 \mu \mathrm{m}$, which was $36-42 \%$ (Figure 1). The application of such Portland cements allows reducing the duration of curing before heat-steaming treatment of concrete.

Смирнова О.М. Совместимость портландцемента и суперпластификаторов на поликарбоксилатной основе для получения высокопрочного бетона сборных конструкций // Инженерно-строительный журнал. 2016. № 6(66). C. 12-22. 

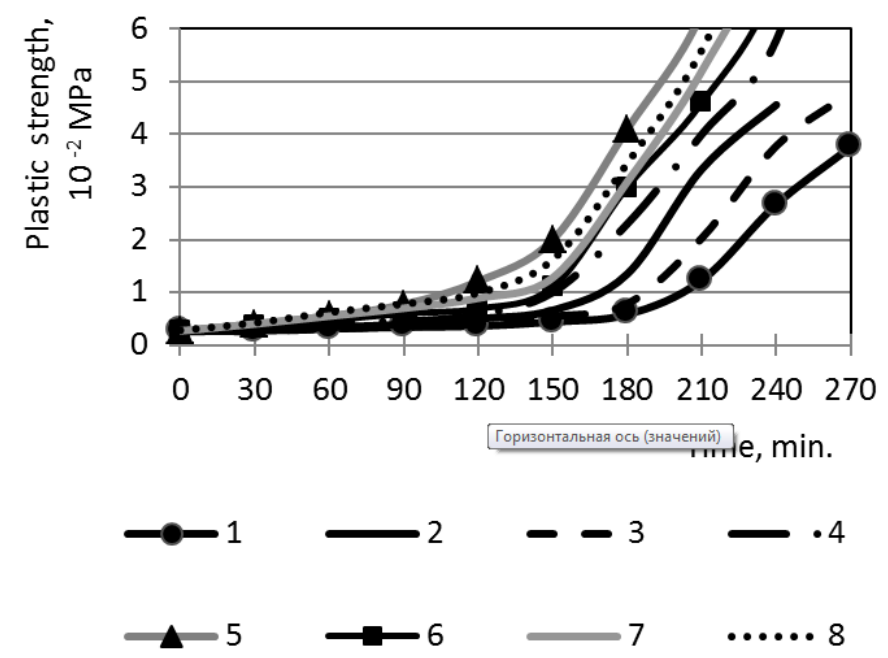

Figure 1. Influence of Portland cements on plastic strength development cement paste of equal fluidity

It was stated that the required strength of concrete of class B40 (34.9 MPa) after the heat-steaming treatment duration of 12 hours at isothermal temperature of $40{ }^{\circ} \mathrm{C}$, can be obtained on Portland cements with the content of grains of size less than $3 \mu \mathrm{m}$ within 17-21\% (Figure 2).

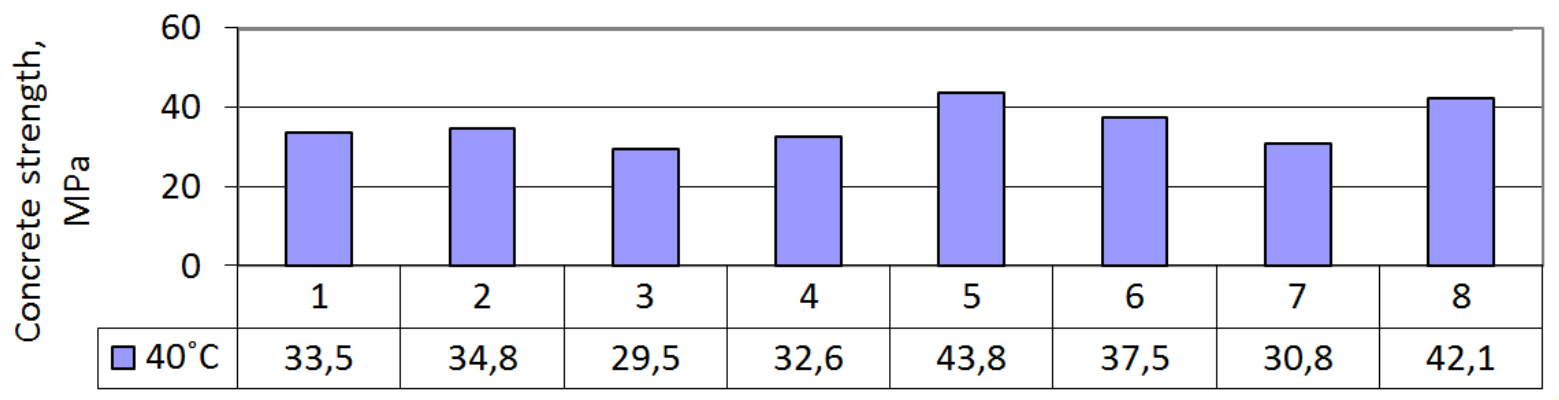

Figure 2. Concrete strength after the heat-steaming treatment duration of 12 hours at isothermal temperature of $40^{\circ} \mathrm{C}$

However, not always the high value of early concrete strength on Portland cements, containing the defined number of fine particles is a characteristic that guarantees the high early strength of concrete on these Portland cements with polycarboxylate-based superplasticizers.

The water-reducing effect of polycarboxylate-based superplasticizers depends on the chemical and mineralogical compositions of cement (Figures 3-4). It is established that the increasing of $\mathrm{C}_{3} \mathrm{~A}$ in Portland cement results in the decreasing of the water-reducing effect of polycarboxylate-based superplasticizers. This was also confirmed in fresh concrete mixes of equal workability when comparing the water-reducing effect of Sika Viscocrete 20 Gold and Glenium ACE 430 (Figure 5). The content of $\mathrm{SO}_{3}$ and alkaline metals in Portland cement No. 1, 2, 3 was almost the same, so their influence on the plasticizing action of admixtures can be neglected. Reduction of water consumption within the limits of $16 \%$ was received in concrete mixtures on Portland cement containing $\mathrm{C}_{3} \mathrm{~A}$ about $6.5 \%$ with the introduction of $0.4 \%$ of polycarboxylate-based superplasticizers and $0.8 \%$ of polycarboxylate-based superplasticizers - on Portland cement containing $\mathrm{C}_{3} \mathrm{~A}$ about $9.9 \%$. With the increase of dosage of polycarboxylate-based superplasticizers the difference between their water-reducing effects in fresh concrete on these Portland cements is decreased. 


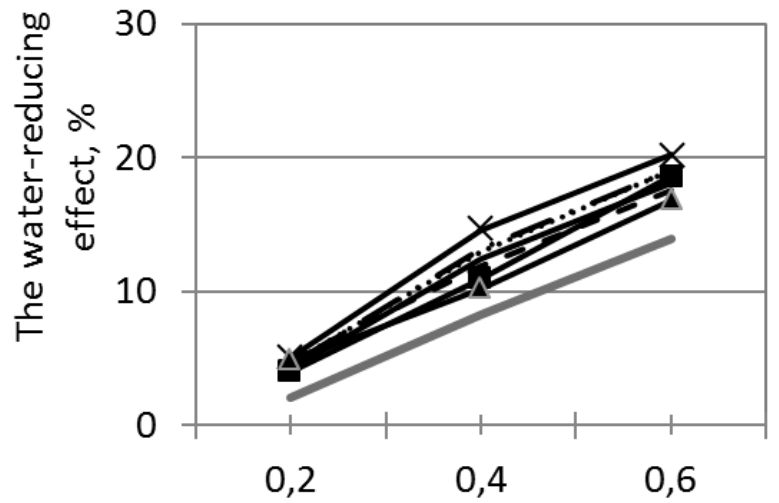

Glenium ACE 430, \%

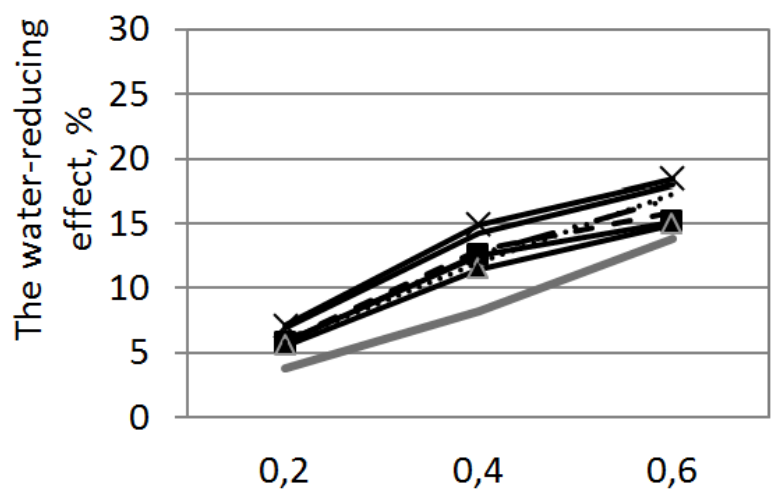

Sika Viscocrete 20Gold, \%

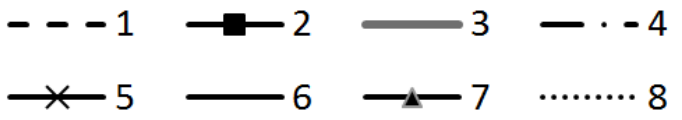

Figure 4. The water-reducing effect of Sika Viscocrete 20 Gold depending on cement
Figure 3. The water-reducing effect of Glenium ACE 430 depending on cement 8

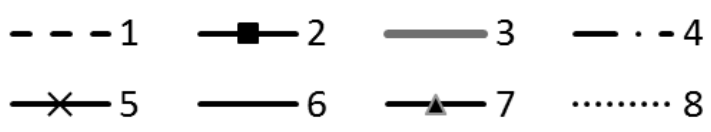

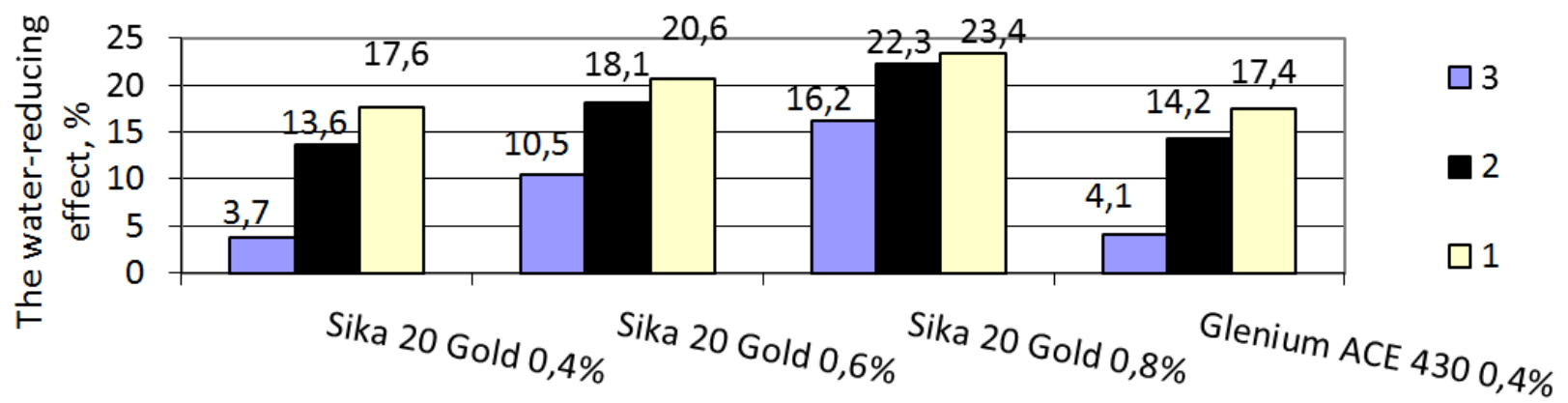

Figure 5. The water-reducing effect of polycarboxylate-based superplasticizers in the stiff fresh concrete mixes depending on cement

In fresh concrete containing polycarboxylate-based superplasticizers and Portland cements with a high content of alkali metals in 8-15 minutes from the moment of water addition there was observed the rapid loss of workability. This agrees with the data obtained by calorimetric measurements on cement pastes with polycarboxylate-based superplasticizers (Figures 6-9). The influence of alkali metal content in cement on the value of first peak of heat flow curve was shown. In the cement paste on Portland cement No. $2\left(\mathrm{Na}_{2} \mathrm{O}_{\text {equiv }}=0.55\right)$ the first peak appears in 3-5 minutes, i.e. actually in the period of preparation of fresh concrete mix. When increasing the alkali metal content in cement to $\mathrm{Na}_{2} \mathrm{O}_{\text {equiv }}=1.15$ the first peak appears in 8-12 minutes. According to G. Verbek [28] the value of heat flow is proportional to the number of hydrate phases, therefore, in case of Portland cements with high content of alkali metals there occurs the intensive growth of hydrate phases and the fast loss of workability of fresh concrete mix. The second peak of heat flow curve was noted on Portland cements No. 5 and 8 earlier than on the others, which agrees with the data of more high strength concrete on these cements at the age of 12 hours.

Смирнова О.М. Совместимость портландцемента и суперпластификаторов на поликарбоксилатной основе для получения высокопрочного бетона сборных конструкций // Инженерно-строительный журнал. 2016. № 6(66). C. 12-22. 


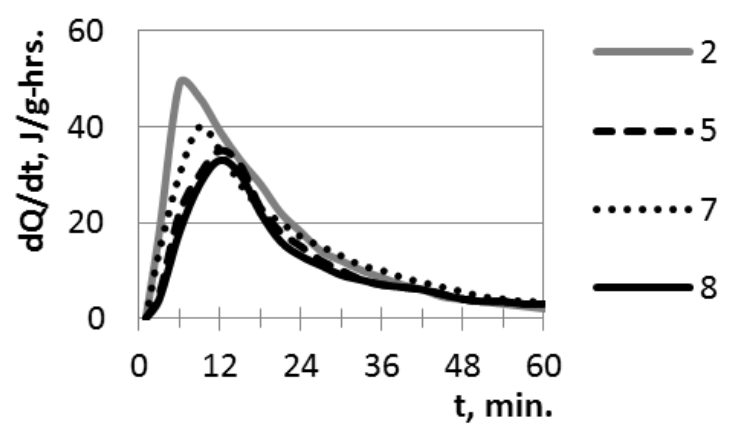

Figure 6. Heat rate of Portland cements with Sika Viscocrete 20 Gold $0.4 \%$ during first hour of hydration

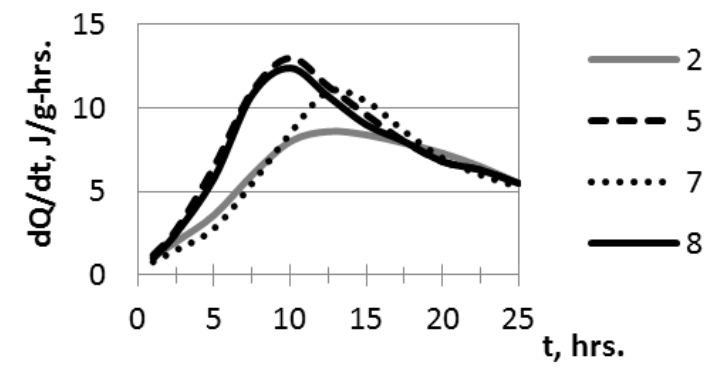

Figure 8. Heat rate of Portland cements with Sika Viscocrete 20 Gold $0.4 \%$ during 25 hours of hydration

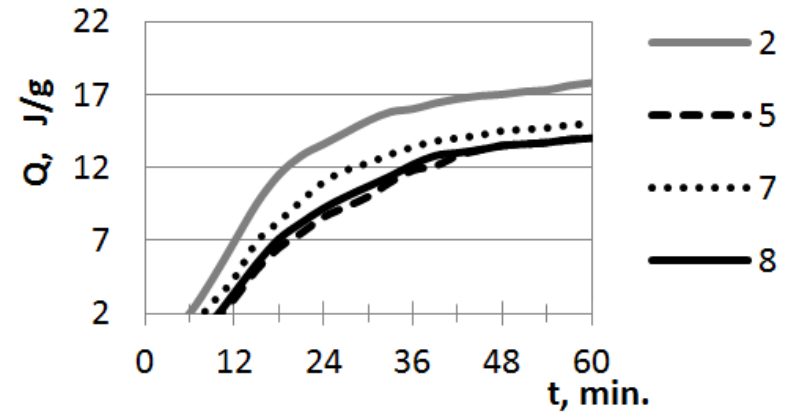

Figure 7. Cumulative heat of Portland cements with Sika Viscocrete 20 Gold $0.4 \%$ during first hour of hydration

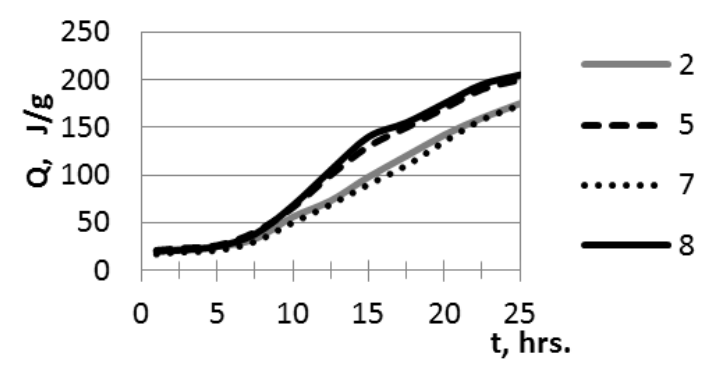

Figure 9. Cumulative heat of Portland cements with Sika Viscocrete 20 Gold $0.4 \%$ during 25 hours of hydration

In order to avoid the loss of workability of fresh concrete with polycarboxylate-based superplasticizers on Portland cements, containing increased quantity of alkaline metals, it is necessary to add the mixing water in two stages. The polycarboxylate-based superplasticizers should be added with the second part of mixing water or it is necessary to increase the duration of mixing up to 1-2 minutes. In the absence of the possibility of adding the mixing water in the two stages it is necessary to increase the total quantity of the mixing water up to $5-7 \%$. However, the increase of mixing water leads to the reducing the early concrete strength and does not allow to receive the significant saving of Portland cement.

According to the results of studies of eight Portland cements it turned out that to ensure the high water-reducing effect of polycarboxylate-based superplasticizers and to eliminate the rapid loss of workability of fresh concrete, the recommended content of the $\mathrm{C}_{3} \mathrm{~A}, \mathrm{SO}_{3}, \mathrm{Na}_{2} \mathrm{O}_{\text {equiv }}$ in Portland cements should be within $4.0-7.0 \% ; 2.57-2.82 \% ; 0.52-0.79 \%$ respectively.

When comparing the effectiveness of admixtures such as Sika Viscocrete 20 Gold and Glenium ACE 430 in the studied Portland cements in order to ensure the necessary strength of concrete (class B40) after the heat-steaming treatment at the isothermal temperature of $40{ }^{\circ} \mathrm{C}$ and the duration of 12 hours, it was established that the maximum reduction of Portland cement consumption can be obtained with the Portland cement, with the content of cement grains of size less than $3 \mu \mathrm{m}$ with $17 \%$ and content of $\mathrm{C}_{3} \mathrm{~A}, \mathrm{SO}_{3}, \mathrm{Na}_{2} \mathrm{O}_{\text {equiv }}$ within the limits mentioned above (Figure 10).

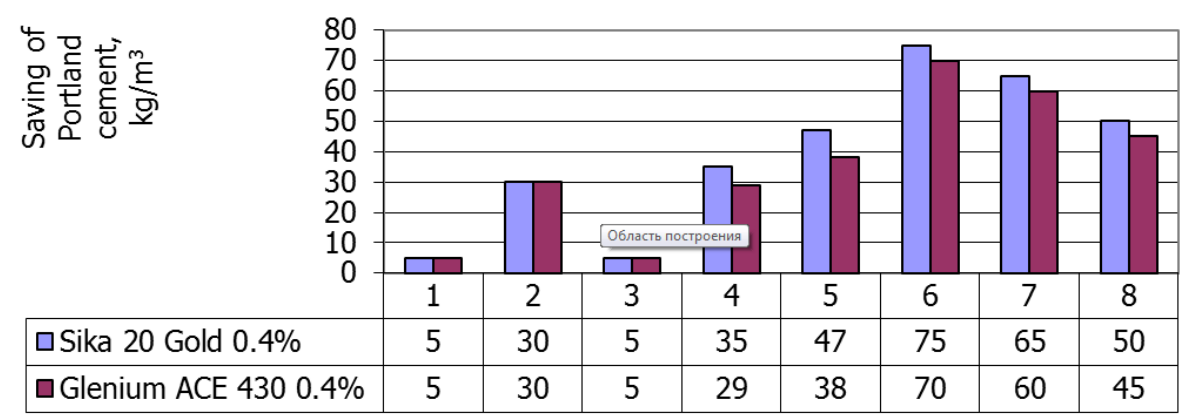

Figure 10. Saving of Portland cement after the heat-steaming treatment at $40^{\circ} \mathrm{C}$ and the duration of 12 hours

Smirnova O.M. Compatibility of portland cement and polycarboxylate-based superplasticizers in high-strength 
The dependences of concrete strength after the heat-steaming treatment at temperature $40{ }^{\circ} \mathrm{C}$ and the duration of 12 hours on the Portland cement consumption and admixture dosage were obtained. Regression equations were calculated, which allows to choose the concrete compositions depending on the required concrete strength at the age of 12 hours. Variable factors were: admixture dosage $-\mathrm{X} 1$ (\%) and Portland cement consumption - X2 $(\mathrm{kg})$. The regression equations, obtained as a result of statistical data processing are the following:

$$
\text { 1. } R=38.837+3.158 X 1+13.1 \times 2+0.303 \times 1^{2}+6.428 \times 2^{2}-2.150 \times 1 X 2
$$

where X1 - dosage of Sika 20 Gold.

$$
\text { 2. } R=40.676+0.713 \times 1+3.970 \times 2-3.098 \times 1^{2}-2.048 \times 2^{2}-2.070 \times 1 \times 2 \text {, }
$$

where X1 - dosage of Glenium ACE 430.

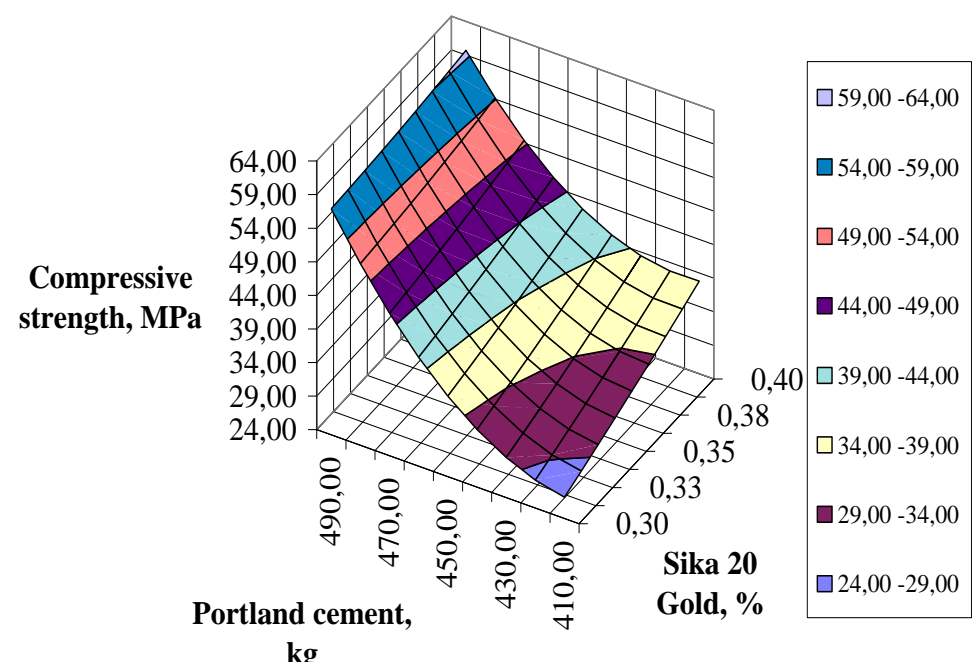

Figure 11. The dependence of concrete strength after the heat-steaming treatment at $40{ }^{\circ} \mathrm{C}$ and the duration of 12 hours on the cement consumption and admixture dosage

Checking adequacy according to the criterion of the Fisher in the level of reliability of 0.95 showed the suitability of mathematical models for the description of the investigated dependencies. In Figures 11 and 12 one can see the graphical representation of mathematical models. The use of admixtures in optimal quantity: Sika Viscocrete 20 Gold of $0.38 \%$, Glenium ACE $430-0.4 \%$ made it possible to reduce Portland cement consumption by $15 \%$ and the isothermal temperature of heat-steaming treatment from $80^{\circ} \mathrm{C}$ to $40^{\circ} \mathrm{C}$. The concrete strength of samples with admixtures at the age of 28 and 360 days was actually equal to the samples without admixtures.

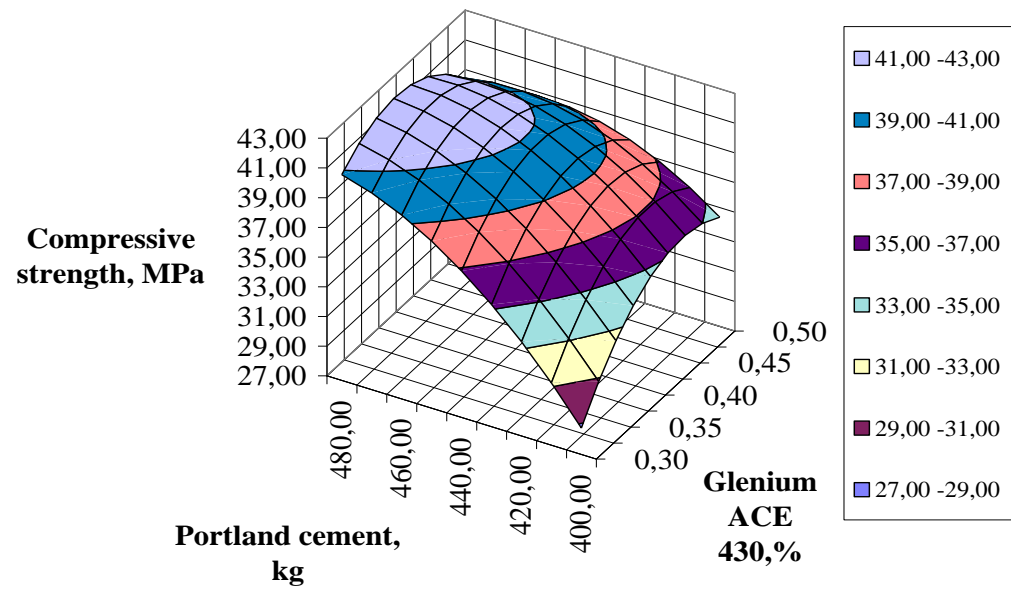

Figure 12. The dependence of concrete strength after the heat-steaming treatment at $40{ }^{\circ} \mathrm{C}$ and the duration of 12 hours on the cement consumption and admixture dosage

Смирнова О.М. Совместимость портландцемента и суперпластификаторов на поликарбоксилатной основе для получения высокопрочного бетона сборных конструкций // Инженерно-строительный журнал. 2016. № 6(66). C. 12-22. 
When comparing the shape and size of $\mathrm{C}-\mathrm{S}-\mathrm{H}$ phases by means of scanning electron microscopy it could be seen that the samples of the cement stone at the age of 12 hours with the admixture of Sika Viscocrete 20 Gold $(0.4 \%)$ are much finer and the structure of C-S-H phases is much denser (Figures 13-14), which increases the number of contacts between C-S-H phases and helps to increase the strength of cement stone.

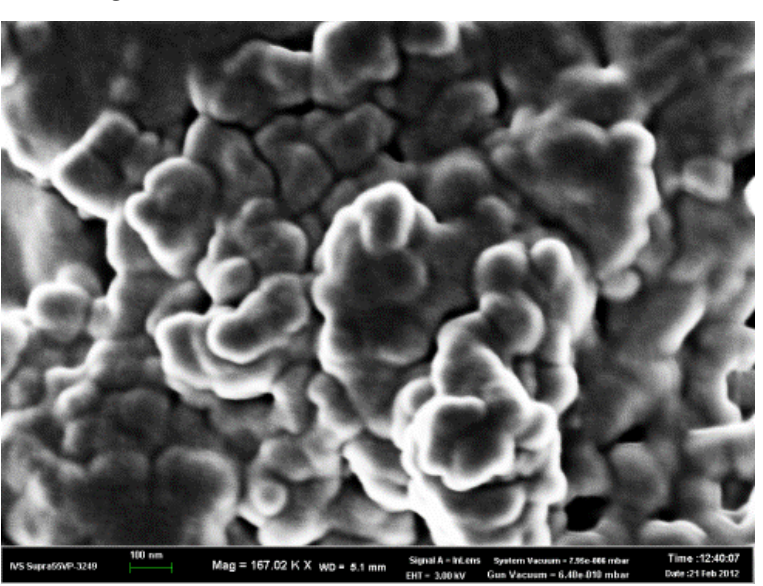

Figure 13. The structure of C-S-H phases in sample without admixture after

the heat-steaming treatment at $40{ }^{\circ} \mathrm{C}$ and the duration of 12 hours

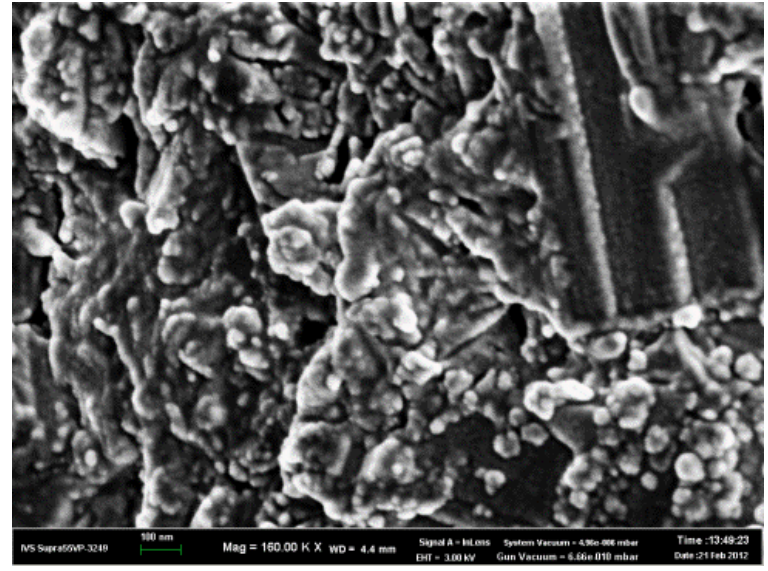

Figure 14. The structure of C-S-H phases in sample with admixture after

the heat-steaming treatment at $40^{\circ} \mathrm{C}$ and the duration of 12 hours

The $\mathrm{C}-\mathrm{S}-\mathrm{H}$ that forms in the hydration of Portland cement has variable stoichiometry depending on the water to cement ratio, curing conditions and use of supplementary cementitious materials [29, 30]. According [31] there are two types of $\mathrm{C}-\mathrm{S}-\mathrm{H}$ in hydrated Portland cement: low density and high density. The low-density C-S-H phase has a mean stiffness of about $22 \mathrm{GPa}$ while the mean stiffness is about $29 \mathrm{GPa}$ for high-density C-S-H.

\section{Conclusions}

1. The results of the research can be used in the production of precast prestressed reinforced concrete with polycarboxylate-based superplasticizers on the existing technological lines of plants with double turnover of moulds per day. The influence of chemical and mineralogical compositions of Portland cements should be taken into account to ensure the high water-reducing effect of these admixtures with their small dosage.

2. The optimal dosages of polycarboxylate-based superplasticizers, requirements to the granulometric and chemical-mineralogical compositions of Portland cements with the purpose of reducing the cement consumption and providing the required concrete strength after the heat-steaming treatment at $40^{\circ} \mathrm{C}$ have been defined.

3. According to the results of studies of eight Portland cements it turned out that to ensure the high water-reducing effect of polycarboxylate-based superplasticizers and to eliminate the rapid loss of workability of fresh concrete, the recommended content of the $\mathrm{C}_{3} \mathrm{~A}, \mathrm{SO}_{3}, \mathrm{Na}_{2} \mathrm{O}_{\text {equiv }}$ in Portland cements should be within 4.0-7.0\%; 2.57-2.82\%; 0.52-0.79\% respectively.

4. It was stated that the required strength of concrete of class B40 (34.9 MPa) after the heatsteaming treatment duration of 12 hours at isothermal temperature of $40^{\circ} \mathrm{C}$, can be obtained on Portland cements with the content of grains of size less than $3 \mu \mathrm{m}$ within $17-21 \%$.

5. The use of admixtures in quantity: Sika Viscocrete 20 Gold of $0.38 \%$, Glenium ACE $430-$ $0.4 \%$ made it possible to reduce Portland cement consumption by $15 \%$ and the isothermal temperature of heat-steaming treatment from $80^{\circ} \mathrm{C}$ to $40{ }^{\circ} \mathrm{C}$ with providing the required concrete strength after the heat-steaming treatment.

\section{References}

1. Serenko A.F., Petrova T.M. Besproparochnaya tekhnologiya proizvodstva podrelsovykh konstruktsiy [Nosteaming technology of under-railway sleepers]. M.: FGBOU Uchebno-metodicheskiy tsentr po obrazovaniyu na zheleznodorozhnom transporte, 2012. 136 p. (rus)

2. Bazhenov Yu.M., Kalashnikov V.I., Demyanova V.S.

\section{Литература}

1. Серенко А.Ф., Петрова Т.М. Беспропарочная технология производства подрельсовых конструкций М.: ФГБОУ Учебно-методический центр по образованию на железнодорожном транспорте, 2012. $136 \mathrm{c}$.

2. Баженов Ю.М., Калашников В.И., Демьянова В.С.

Smirnova O.M. Compatibility of portland cement and polycarboxylate-based superplasticizers in high-strength 
Vysokokachestvennyy beton [High-performance concrete]. M.:Izd-vo ASV, 2007. 555 p. (rus)

3. Petrova T.M., Smirnova O.M., Stasiuk I.A., Dzhashi N.A. Influence of Portland cement properties on the early strength of concrete with polycarboxylate-based superplasticizers. Proceedings of 18. Internationale Baustofftagung. IBAUSIL. Weimar, 2012. Pp. 660-667.

4. Calvo G.J.L. Performance of concrete in precast products due to heat curing. Proceedings of XIII International Congress on the chemistry of cement. Madrid, 2011. 183 p.

5. Ozbay E., Gesoglu M., Guneyisi E. Transport properties based multi-objective mix proportioning optimization of high performance concretes. Materials and Structures. 2011. Vol. 44. No. 1. Pp. 139-154.

6. Huang H., Qian C., Zhao F., Qu J., Guo J., Danzinger M. Improvement on microstructure of concrete by polycarboxylate superplasticizer (PCE) and its influence on durability of concrete. Construction and Building Materials. 2016. Vol. 110. Pp. 293-299.

7. Nkinamubanzi P.-C., Mantellato S., Flatt R.J. $16-$ Superplasticizers in practice. Science and Technology of Concrete Admixtures. 2016. Pp. 353-377.

8. Gelardi G., Flatt R.J. 11 - Working mechanisms of water reducers and superplasticizers. Science and Technology of Concrete Admixtures. 2016. Pp. 257-278.

9. Xu L. Study on the relationship of narrow particle size fractions and properties of cement. Proceedings of XIII International Congress on the chemistry of cement. Madrid, 2011. $17 \mathrm{p}$

10. Asghari A.A., Hernandez A.M.L., Feys D., De Schutter G. Which parameters, other than the water content, influence the robustness of cement paste with SCC consistency? Construction and Building Materials. 2016. Vol. 124. Pp. 95-103.

11. Burgos-Montes O., Palacios M., Rivilla P., Puertas F. Compatibility between superplasticizer admixtures and cements with mineral additions. Construction and Building Materials. 2012. Vol. 31. Pp. 300-309.

12. Smirnova O.M. Vysokokachestvennyye betony dlya predvaritelno napryazhennykh zhelezobetonnykh konstruktsiy [High performance concrete for precast prestressed concrete constructions]. Sankt-Peterburg: Izdvo RGPU im.A.I.Gertsena, 2014. 67 p. (rus)

13. Petrova T.M., Smirnova O.M., Shabiev R.O. Some properties of plasticized compositions of Portland cementgranulated blast furnace slag. Proceedings of XIII International Congress on the chemistry of cement. Madrid, 2011. $135 \mathrm{p}$.

14. Alonso M.M., Palacios M., Puertas F. Compatibility between polycarboxylate-based admixtures and blendedcement pastes. Cement and Concrete Composites. 2013. Vol. 35. No. 1. Pp. 151-162.

15. Smirnova O.M. Ispolzovaniye mineralnogo mikronapolnitelya dlya povysheniya aktivnosti portlandtsementa [Use of mineral fillers to increase the Portland cement activity]. Stroitelnyye materialy. 2015. No. 3. Pp. 30-33. (rus)

16. Cheung J., Jeknavorian A., Roberts L., Silva D. Impact of admixtures on the hydration kinetics of Portland cement. Cement and Concrete Research. 2011. Vol. 41. No. 12. Pp. 1289-1309.

17. Janowska-Renkas E. The influence of the chemical structure of polycarboxylic superplasticizers on their effectiveness in cement pastes. Procedia Engineering. 2015. Vol. 108. Pp. 575-583.

18. Plank J., Hirsch C. Impact of zeta potential of early cement hydration phases on superplasticizer adsorption. Cement and Concrete Research. 2007. No. 37. Pp. 537-542.

19. Yu B., Zeng Z., Ren Q., Chen Y., Liang M., Zou H. Study on the performance of polycarboxylate-based superplasticizers synthesized by reversible additionfragmentation chain transfer (RAFT) polymerization. Journal of Molecular Structure. 2016. Vol. 1120. Pp. 171179.

Смирнова О.М. Совместимость портландцемента и суперпластификаторов на поликарбоксилатной основе для получения высокопрочного бетона сборных конструкций // Инженерно-строительный журнал. 2016. № 6(66). C. 12-22.
Высококачественный бетон. М.: Изд-во АСВ, 2007 $555 \mathrm{c}$.

3. Petrova T.M., Smirnova O.M., Stasiuk I.A., Dzhashi N.A Influence of Portland cement properties on the early strength of concrete with polycarboxylate-based superplasticizers // Proceedings of 18. Internationale Baustofftagung. Weimar: IBAUSIL, 2012. Pp. 660-667.

4. Calvo G.J.L. Performance of concrete in precast products due to heat curing // Proceedings of XIII International Congress on the chemistry of cement. Madrid, 2011. $183 \mathrm{p}$.

5. Ozbay E., Gesoglu M., Guneyisi E. Transport properties based multi-objective mix proportioning optimization of high performance concretes // Materials and Structures. 2011. Vol. 44. № 1. Pp. 139-154.

6. Huang H., Qian C., Zhao F., Qu J., Guo J., Danzinger M Improvement on microstructure of concrete by polycarboxylate superplasticizer (PCE) and its influence on durability of concrete // Construction and Building Materials. 2016. Vol. 110. Pp. 293-299.

7. Nkinamubanzi P.-C., Mantellato S., Flatt R.J. 16Superplasticizers in practice // Science and Technology of Concrete Admixtures. 2016. Pp. 353-377.

8. Gelardi G., Flatt R.J. 11 - Working mechanisms of water reducers and superplasticizers // Science and Technology of Concrete Admixtures. 2016. Pp. 257-278

9. Xu L. Study on the relationship of narrow particle size fractions and properties of cement // Proceedings of XIII International Congress on the chemistry of cement. Madrid, 2011. $17 \mathrm{p}$.

10. Asghari A.A., Hernandez A.M.L., Feys D., De Schutter G. Which parameters, other than the water content, influence the robustness of cement paste with SCC consistency? // Construction and Building Materials. 2016. Vol. 124 Pp. 95-103. Compatibility between superplasticizer admixtures and cements with mineral additions // Construction and Building Materials. 2012. Vol. 31. Pp. 300-309.

12. Смирнова О.М. Высококачественные бетоны для предварительно напряженных железобетонных конструкций // СПб: Изд-во РГПУ им.А.И.Герцена. Санкт-Петербург, 2014. 67 с.

13. Petrova T.M., Smirnova O.M., Shabiev R.O. Some properties of plasticized compositions of Portland cementgranulated blast furnace slag // Proceedings of XIII International Congress on the chemistry of cement. Madrid, 2011. $135 \mathrm{p}$.

14. Alonso M.M., Palacios M., Puertas F. Compatibility between polycarboxylate-based admixtures and blendedcement pastes // Cement and Concrete Composites. 2013. Vol. 35. № 1. Pp. 151-162.

15. Смирнова О.М. Использование минерального микронаполнителя для повышения активности портландцемента // Строительные материалы. 2015. № 3. C. 30-33.

16. Cheung J., Jeknavorian A., Roberts L., Silva D. Impact of admixtures on the hydration kinetics of Portland cement // Cement and Concrete Research. 2011. Vol. 41. № 12. Pp. 1289-1309.

17. Janowska-Renkas E. The influence of the chemical effectiveness in cement pastes // Procedia Engineering. 2015. Vol. 108. Pp. 575-583.

18. Plank J., Hirsch C. Impact of zeta potential of early cement hydration phases on superplasticizer adsorption // Cement and Concrete Research. 2007. № 37. Pp. 537-542.

19. Yu B., Zeng Z., Ren Q., Chen Y., Liang M., Zou H. Study on the performance of polycarboxylate-based superplasticizers synthesized by reversible addition-
11. Burgos-Montes O., Palacios M., Rivilla P., Puertas F. structure of polycarboxylic superplasticizers on their 
20. Moratti F., Magarotto R., Mantellato S. Influence of polycarboxylate side chains length on cement hydration and strengths development. Proceedings of XIII International Congress on the chemistry of cement. Madrid, 2011. $248 \mathrm{p}$.

21. Gelardi G., Mantellato S., Marchon D., Palacios M., Eberhardt A.B., Flatt R.J. 9-Chemistry of chemical admixtures. Science and Technology of Concrete Admixtures. 2016. Pp. 149-218.

22. Zeminian N., Magarotto R., Tucci I. Effect of the molecular weight of PCE-based superplasticizers on their interaction with different cements. Proceedings of XIII International Congress on the chemistry of cement. Madrid, 2011. $373 \mathrm{p}$.

23. Kong F.-R., Pan L.-S., Wang C.-M., Zhang D.-L., Xu N. Effects of polycarboxylate superplasticizers with different molecular structure on the hydration behavior of cement paste. Construction and Building Materials. 2016. Vol. 105. Pp. 545-553.

24. Rebinder P.A., Cemenenko N.A. O metode pogruzheniya konusa dlya kharakteristiki strukturno-mekhanicheskikh svoystv plastichno-vyazkikh tel [The method of dipping the cone to characterize structural and mechanical properties of the plastic-viscous bodies]. Doklady Akademii Nauk SSSR [Proceedings of the USSR Academy of Science]. 1949. Vol. LXIV, No. 6. Pp. 835-838. (rus)

25. Riad M.Y., Shoukry S., Sosa E., William G. Prediction of concrete initial setting time in field conditions through multivariate regression analysis. Materials and Structures. 2011. No. 6(44). Pp. 1063-1077.

26. Hassan S., Perrot A., Amziane S. A new look at the measurement of cementitious paste setting by Vicat test. Cement Concrete Res. 2010. No. 5(40). Pp. 681-686.

27. Smirnova O.M. Trebovaniya $\mathrm{k}$ granulometricheskomu sostavu portlandtsementov dlya proizvodstva sbornogo zhelezobetona po maloprogrevnoy tekhnologii [Requirements for particle size distribution of Portland cement for the manufacture of precast concrete with nosteaming technology]. Cement and its applications. 2012. No. 2. Pp. 205-207. (rus)

28. Verbek G. Perevody IV mezhdunarodnogo kongressa po khimii tsementa [Translations of the IV International Congress of cement chemistry]. Moscow: Stroyizdat, 1964. Pp. 335-343. (rus)

29. Taylor H.F.W. Cement chemistry. 2nd edn. Thomas Telford. London, 1997. 476 p.

30. Alizadeh R., Beaudoin J.J., Raki L. Mechanical properties of calcium silicate hydrates. Materials and Structures. 2011. No. 1(44). Pp. 13-28.

31. Constantinides G., Ulm F.-J. The effect of two types of C$\mathrm{S}-\mathrm{H}$ on the elasticity of cement-based materials: results from nanoindentation and micromechanical modeling Cem Concr Res. 2004. No. 1(34). Pp. 67-80.

\section{Olga Smirnova,}

+7(905)2826022; smirnovaolgam@rambler.ru fragmentation chain transfer (RAFT) polymerization // Journal of Molecular Structure. 2016. Vol. 1120. Pp. 171179.

20. Moratti F., Magarotto R., Mantellato S. Influence of polycarboxylate side chains length on cement hydration and strengths development /I Proceedings of XIII International Congress on the chemistry of cement. Madrid, 2011. $248 \mathrm{p}$.

21. Gelardi G., Mantellato S., Marchon D., Palacios M. Eberhardt A.B., Flatt R.J. 9-Chemistry of chemical admixtures // Science and Technology of Concrete Admixtures. 2016. Pp. 149-218.

22. Zeminian N., Magarotto R., Tucci I. Effect of the molecular weight of PCE-based superplasticizers on their interaction with different cements // Proceedings of XIII International Congress on the chemistry of cement. Madrid, 2011. $373 \mathrm{p}$.

23. Kong F.-R., Pan L.-S., Wang C.-M., Zhang D.-L., Xu N. Effects of polycarboxylate superplasticizers with different molecular structure on the hydration behavior of cement paste // Construction and Building Materials. 2016. Vol. 105. Pp. 545-553.

24. Ребиндер, П.А., Семененко, Н.А. О методе погружения конуса для характеристики структурно-механических свойств пластично-вязких тел // Доклады Академии Наук CCCP. 1949. T. LXIV, № 6, C. 835-838.

25. Riad M.Y., Shoukry S., Sosa E., William G. Prediction of concrete initial setting time in field conditions through multivariate regression analysis // Materials and Structures. 2011. № 6(44). Pp. 1063-1077.

26. Hassan S., Perrot A., Amziane S. A new look at the measurement of cementitious paste setting by Vicat test // Cement Concrete Res. 2010. № 5(40). Pp. 681-686.

27. Смирнова О.М. Требования к гранулометрическому составу портландцементов для производства сборного железобетона по малопрогревной технологии // Цемент и его применение. 2012. № 2. С. 205-207.

28. Вербек, Г. Переводы IV международного конгресса по химии цемента. М.: Стройиздат, 1964. С. 335-343.

29. Taylor H.F.W. Cement chemistry. 2nd edn. Thomas Telford. London, 1997. $476 \mathrm{p}$.

30. Alizadeh R., Beaudoin J.J., Raki L. Mechanical properties of calcium silicate hydrates // Materials and Structures. 2011. № 1(44). Pp. 13-28.

31. Constantinides G., Ulm F.-J. The effect of two types of C$\mathrm{S}-\mathrm{H}$ on the elasticity of cement-based materials: results from nanoindentation and micromechanical modeling // Cem Concr Res. 2004. № 1(34). Pp. 67-80.

Ольга Михайловна Смирнова, $+7(905) 2826022$

эл. почта: smirnovaolgam@rambler.ru 